JIIA, VOLUME 6 No. 3, AGUSTUS 2018

\title{
PROYEKSI STOKASTIK PRODUKSI KEDELAI DI INDONESIA
}

\author{
(The Stochastic Forecasting of Soybean Production in Indonesia) \\ Yurlia Pitasari, Agus Hudoyo, Achdiansyah Soelaiman
}

Jurusan Agribisnis, Fakultas Pertanian, Universitas Lampung, Jl. Prof. Dr. Soemantri Brojonegoro No.1

Bandar Lampung 35141, Telp. 085768867288, e-mail: yurlia_p@yahoo.co.id

\begin{abstract}
Soybean is one of vegetable protein sources. It is so important that the government targets self-sufficiency on this commodity. Its target is 3.00 million tons in 2019, i.e. more than three times of the production in 2015. A production target is better stochastically forecasted that its result is an interval at a certain probability level. There were some studies that forecasted productions of soybean. However, their results were not as the intervals. Therefore, the objective of this research is for stochastically forecasting the soybean production. Its data are time series data obtained from the FAO and the Indonesian Statistics Central Bureau. Data were analyzed by using econometrics. The result of forecasting is the soybean production will be 0.99 million tons in 2019 with the 95\% confidence interval between 0.94 and 1.05 million tons.
\end{abstract}

Key words: Soybean, production, forecast

\section{PENDAHULUAN}

Kedelai merupakan salah satu sumber pangan protein nabati. Selain dikonsumsi dalam bentuk segar, kedelai juga dikonsumsi dalam bentuk olahan makanan seperti tahu, tempe, dan kecap. Total kebutuhan kedelai untuk berbagai macam kebutuhan pada tahun 2015 yaitu 2,56 juta ton. Sementara itu, produksi kedelai untuk tahun yang sama yaitu 0,96 juta ton (BPS 2017). Hal ini berarti produksi kedelai hanya mencukupi $37,50 \%$ dari jumlah kebutuhannya.

Berdasarkan kondisi tersebut, pemerintah mencanangkan swasembada kedelai. Produksi kedelai ditargetkan sebesar 3,00 juta ton pada 2019, atau tiga kali lipat lebih dari produksi pada 2015. Target produksi yang sangat tinggi tersebut merupakan proyeksi produksi yang deterministik. Proyeksi yang baik, selain memperhatikan faktorfaktor yang mempengaruhi variabel yang diteliti juga mempertimbangkan adanya faktor ketidakpastian. Hasil dari suatu penaksiran yang mempertimbangkan faktor ketidakpastian dapat berupa perkiraan selang pada peluang tersebut atau disebut perkiraan stokastik.

Proyeksi produksi kedelai pernah dilakukan oleh Aldillah (2015) dan Komalasari (2008). Kedua peneliti ini menggunakan analisis statistika. Walaupun demikian, hasil proyeksinya hanya berupa proyeksi satu titik dan tidak disertai selang proyeksinya. Oleh sebab itu, penelitian ini bertujuan untuk memproyeksikan produksi kedelai untuk tahun 2018-2020 dengan menggunakan pendekatan stokastik.

\section{METODE PENELITIAN}

Data yang digunakan dalam penelitian ini yaitu data runtun waktu pada periode 1961-2015 yang bersumber dari BPS dan FAO. Data kemudian diolah menggunakan metode ekonometrika dengan model kuadrat terkecil (OLS). Metode tersebut juga pernah digunakan oleh Lestari (2015) untuk memproyeksikan produksi dan konsumsi telur ayam di Lampung. Model empiris produksi kedelai yang digunakan untuk proyeksi dapat dilihat pada Persamaan 1.

$$
\begin{aligned}
& Y_{t}=a+b_{1} X_{1 t}+b_{2} X_{2 t}+b_{3} D_{l t}+b_{4} D_{2 t}+b_{5} D_{3 t}+e_{1 t}(1) \\
& \text { Keterangan : } \\
& \mathrm{Y}=\text { Produksi kedelai (juta ton) } \\
& \mathrm{a}=\text { Intersep } \\
& \mathrm{b}_{1} . . \mathrm{b}_{4}=\text { Penduga koefisien regresi } \\
& \mathrm{X}_{1}=\text { Luas panen kedelai (juta hektar) } \\
& \mathrm{X}_{2}=\text { Benih kedelai (juta ton) } \\
& \mathrm{D}_{1}=\text { Minat petani } 1(0 \text { : periode } 1961-1984,1 \\
& \text { : lainnya) } \\
& \mathrm{D}_{2}=\text { Minat petani } 2(0 \text { : periode } 1985-1995,1 \\
& \text { : lainnya) } \\
& \mathrm{D}_{3}=\text { Minat petani } 3(0 \text { : periode } 1996-2007,1 \\
& \text { : lainnya) } \\
& \mathrm{t}=\text { Tahun 1961, 1962, ...., } 2015 \\
& \mathrm{e}_{1}=\text { Galat }
\end{aligned}
$$


Produksi kedelai secara umum dipengaruhi oleh beberapa faktor seperti luas panen, benih, pupuk, pestisida, tenaga kerja, dan teknologi. Namun, variabel yang digunakan untuk memproyeksikan produksi kedelai hanya terdiri dari luas panen dan benih kedelai. Faktor-faktor produksi lainnya seperti pupuk, pestisida, dan tenaga kerja tidak dimasukkan ke dalam model karena data tidak tersedia dalam skala nasional. Meskipun tidak dimasukkan dalam model, variabel-variabel ini penggunaannya proporsional dengan luas panen.

Tingkat produksi kedelai selain dipengaruhi oleh faktor-faktor produksinya juga dapat dipengaruhi oleh minat petani dalam menanam kedelai. Berdasarkan data perkembangan produksi dan luas panen kedelai, minat petani dalam menanam kedelai dapat digolongkan menjadi empat periode (Tabel 1). Secara empiris, variabel minat petani dalam menanam kedelai dapat dilihat pada Persamaan 1. Nilai variabel boneka minat petani dalam menanam kedelai untuk setiap periode dapat dilihat pada Tabel 1.

Selanjutnya, dilakukan proyeksi luas panen dan penggunaan benih kedelai untuk periode 2018 hingga 2020. Metode analisis yang digunakan untuk memproyeksikan yaitu model AutoRegressive Integrated Moving Average (ARIMA). Berikut adalah model yang digunakan untuk memproyeksikan variabel luas panen dan benih kedelai (Santoso 2009).

$X_{n}=\beta_{1} X_{t-1}+\beta_{p} X_{t-p}-e_{t}-\alpha_{1} e_{t-1}-. .-\alpha_{q} e_{t-q}$

Keterangan :

$X_{n}=$ Variabel terikat (luas panen/benih)

$\beta=$ Parameter AR yang tidak diketahui

$\alpha=$ Parameter MA yang tidak diketahui

$\mathrm{X}_{\mathrm{t}-1}=$ Nilai variabel terikat pada waktu ke $\mathrm{t}-1$

$\mathrm{e}_{\mathrm{t}-1}=$ Error random pada waktu $\mathrm{t}-1$

$\mathrm{e}_{\mathrm{t}}=$ Error random $\mathrm{ke}-\mathrm{t}$

Tabel 1. Variabel minat petani menanam kedelai

\begin{tabular}{cccc}
\hline Minat petani & \multicolumn{3}{c}{ Nilai variabel boneka } \\
\cline { 2 - 4 } periode & D1 & D2 & D3 \\
\hline $1961-1984$ & 0 & 1 & 1 \\
$1985-1995$ & 1 & 0 & 1 \\
$1996-2007$ & 1 & 1 & 0 \\
$2008-2015$ & 1 & 1 & 1 \\
\hline
\end{tabular}

\section{HASIL DAN PEMBAHASAN}

\section{Perkembangan Produksi, Luas Panen, dan Produktivitas Lahan Kedelai}

Perkembangan produksi kedelai di Indonesia periode 1961-2015 dapat dilihat pada Gambar 1. Secara garis besar, fluktuasi produksi kedelai mengikuti fluktuasi luas panennya dan dapat digolongkan menjadi empat periode, yaitu : (1) produksi kedelai rendah dan pertumbuhannya meningkat sedikit; (2) produksi kedelai tinggi dan pertumbuhannya meningkat drastis; (3) produksi kedelai tinggi dan pertumbuhannya menurun drastis; (4) produksi kedelai rendah dan pertumbuhannya meningkat sedikit. Penggolongan tersebut dilihat dari rata-rata produksi dan pertumbuhannya (Tabel 2).

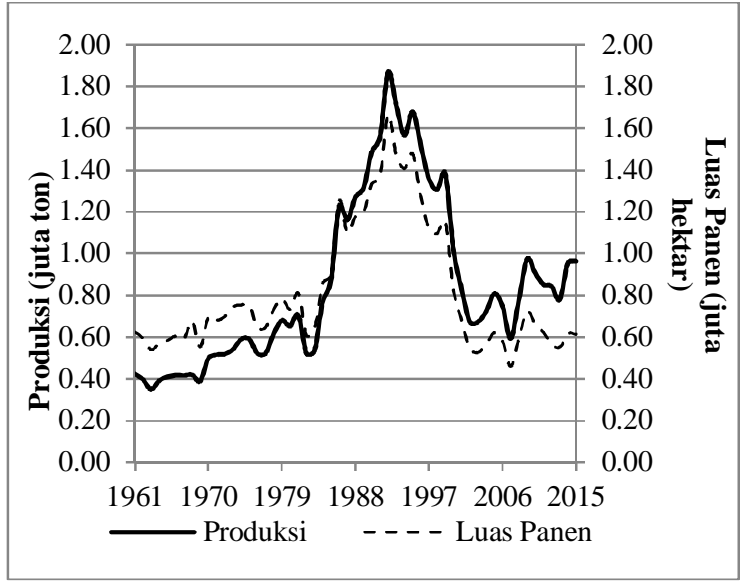

Sumber : FAO dan BPS 2017, diolah.

Gambar 1. Perkembangan luas panen dan produksi kedelai di Indonesia periode 1961-2015

Tahun 1961 hingga 1984 produksi kedelai cukup stabil dan meningkat yaitu dari 0,43 juta ton menjadi 0,77 juta ton. Akan tetapi, angka produksi terendah sepanjang periode 1961-2015 terjadi pada periode ini yaitu 0,35 juta ton tahun 1963 .

Tabel 2. Rata-rata produksi kedelai per periode

\begin{tabular}{ccc}
\hline $\begin{array}{c}\text { Minat petani } \\
\text { periode }\end{array}$ & $\begin{array}{c}\text { Rata-rata Produksi } \\
\text { kedelai } \\
\text { (juta ton/tahun) }\end{array}$ & $\begin{array}{c}\text { Pertumbuhan } \\
\text { produksi kedelai } \\
\text { (\%/tahun) }\end{array}$ \\
\hline $1961-1984$ & 0,52 & 3,31 \\
$1985-1995$ & 1,43 & 6,99 \\
$1996-2007$ & 0,97 & $-6,77$ \\
$2008-2015$ & 0,88 & 3,41 \\
\hline
\end{tabular}


Secara garis besar, rata-rata produksi kedelai dan luas panen kedelai terendah terjadi pada periode 1961-1984 yaitu masing-masing sebesar 0,52 juta ton dan 0,67 juta hektar per tahun dengan laju pertumbuhan mencapai $3,31 \%$ per tahun.

Periode 1985-1995 produksi kedelai mulai menunjukan perkembangan yang cukup pesat. Rata-rata produksi dan luas panenya mencapai 1,43 juta ton dan 1,30 juta hektar per tahun. Produksi kedelai mencapai puncaknya terjadi pada periode ini yaitu sebesar 1,87 juta ton tahun 1992 . Laju pertumbuhan produksi kedelai adalah 6,99\% per tahun.

Kondisi produksi kedelai sejak akhir tahun 1995 mengalami keterpurukan. Produksi kedelai mengalami penurunan secara drastis periode 19962007. Rata-rata produksi kedelai saat itu mencapai 0,97 juta ton per tahun. Produksi kedelai terendah terjadi tahun 2007 yaitu hanya mencapai 0,59 juta ton. Laju penurunan produksi kedelai pada periode ini yaitu $6,77 \%$ per tahun. Penurunan produksi kedelai mengikuti arah luas panennya. Hal ini berarti terindikasi adanya persaingan lahan dengan komoditas pertanian lainnya seperti jagung. Minat petani menanam kedelai menurun sejak benih jagung hibrida mulai diterapkan. Rata-rata produksi jagung meningkat dari periode sebelumnya (1985-1995) yaitu 6,44 juta ton per tahun menjadi 10,47 juta ton per tahun pada periode 1996-2007.

Minat petani menanam kedelai terus mengalami penurunan periode 2008-2015. Angka produksi kedelai rata-rata saat itu sebesar 0,88 juta ton per tahun. Disisi lain, produksi jagung terus mengalami peningkatan dengan adanya perkembangan benih jagung hibrida. Rata-rata produksi jagung periode 2008-2014 telah mencapai 18,12 juta ton per tahun.

Tolak ukur keberhasilan suatu kegiatan usahatani dalam menghasilkan komoditas pertanian dapat dilihat dari seberapa besar nilai produktivitasnya. Besarnya nilai produktivitas ditentukan oleh jumlah output yang dihasilkan dari penggunaan input sebagai komponen dasar. Produktivitas merupakan suatu nilai yang menggambarkan seberapa baik faktor produksi dimanfaatkan hingga mencapai hasil yang optimal (Mubyarto 1989).

Perkembangan produktivitas lahan kedelai di Indonesia dapat dilihat pada Gambar 2.

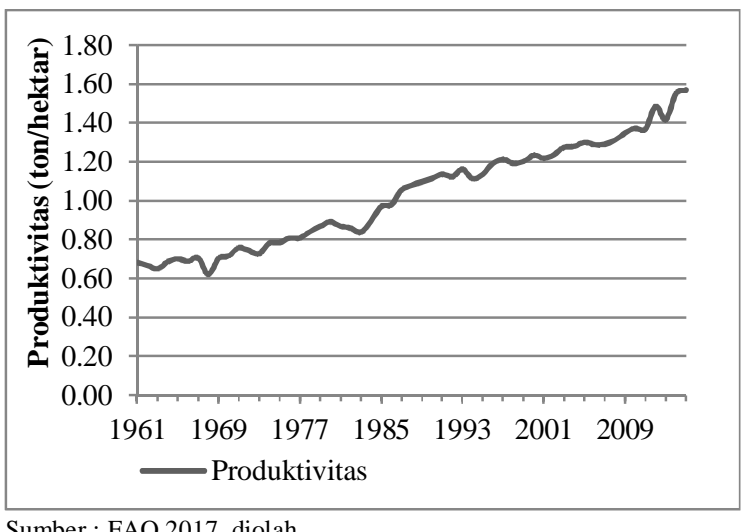

Sumber : FAO 2017, diolah.

Gambar 2. Perkembangan produktivitas lahan kedelai di Indonesia periode 19612015.

Menurut data dari FAO dan BPS (2017), produktivitas lahan kedelai periode 1961-2015 rata-rata meningkat dengan laju pertumbuhan 1, $61 \%$ per tahun. Produktivitas lahan kedelai terendah terjadi tahun 1968, yaitu hanya mencapai 0,62 ton per hektar. Produktivitas lahan kedelai terus mengalami peningkatan dan menyentuh angka 1,57 ton per hektar tahun 2015 .

Meskipun demikian, angka produktivitas lahan kedelai masih sangat rendah jika dibandingkan dengan negara penghasil kedelai lainnya, seperti Amerika dan Brazil. Produktivitas lahan kedelai di Amerika dan Brazil masing-masing mencapai 3,20 dan 2,87 ton per hektar tahun 2014 (FAO 2017). Sementara itu, dibandingkan dengan komoditas pesaingnya yaitu jagung. Produktivitas lahan jagung tertinggi tahun 2015, yaitu sudah mencapai 5,18 ton per hektar atau 3 kali lipat lebih besar dari produktivitas lahan kedelai.

\section{Proyeksi Produksi Kedelai di Indonesia.}

Model regresi linear dapat dipergunakan untuk membuat estimasi atau perkiraan, pengujian hipotesa dan proyeksi. Suatu model dapat menghasilkan pendugaan yang tepat dan tidak bias, jika model tersebut memenuhi kriteria model terbaik (bebas dari pelanggaran asumsi klasik). Kategori model yang bebas pelanggaran asumsi klasik, diantaranya; tidak terdapat otokorelasi antara kesalahan penganggu, tidak ada multikolenieritas, dan kesalahan pengganggu $\left(e_{i}\right)$ mempunyai varian yang sama (homoskedastik) (Supranto 1983).

Indikator model estimasi yang bebas dari pelanggaran asumsi klasik adalah memiliki nilai 
koefisien determinasi tinggi, memiliki nilai standard error terendah, secara uji t hitung memiliki tingkat signifikan nyata, dan secara bersama-sama variabel dalam model berpengaruh signifikan.

Hasil uji multikolinear pada model proyeksi produksi kedelai (Tabel 3), menunjukkan bahwa kedua model tidak ada multikolinear. Akan tetapi, model persamaan dengan OLS nilai $D W$ berada pada daerah tanpa keputusan. Selanjutnya, dengan menggunakan model FGLS model estimasi yang dihasilkan dinyatakan bebas masalah autokorelasi. Oleh sebab itu, model yang digunakan untuk memproyeksikan produksi kedelai adalah model FGLS.

Nilai koefisien daterminasi atau $\mathrm{R}$ square dapat memperlihatkan seberapa bagus model regresi yang dibentuk oleh interaksi variabel bebas dan variabel terikat. Nilai $\mathrm{R}$ square model FGLS adalah 99,6\%. Ditafsirkan sebesar 99,6\% bahwa variabel bebas $X$ memiliki pengaruh terhadap variabel $\mathrm{Y}$ dan sisanya dipengaruhi oleh faktorfaktor lain diluar variabel X (Tabel 3).

Pengaruh variabel bebas terhadap produksi kedelai secara bersama-sama dapat dilihat dari uji F. Jika nilai Sig. $<\alpha$, maka faktor-faktor produksi kedelai secara bersama-sama berpengaruh terhadap jumlah produksi kedelai dan berlaku sebaliknya. Hasil regresi data produksi di atas menunjukkan bahwa faktor-faktor produksi kedelai yang dimasukkan dalam model (variabel luas panen, benih, dan minat petani) secara bersama-sama berpengaruh nyata terhadap jumlah produksi kedelai.

Uji t digunakan untuk melihat pengaruh masingmasing variabel bebas dalam model terhadap varibel terikatnya. Pada model produksi kedelai masing-masing variabel bebas (luas panen, jumlah benih, dan minat petani dalam menanam kedelai) berpengaruh nyata terhadap produksi kedelai dengan alpha $5 \%(\alpha=0,05)$. Selanjutnya, dengan menganggap variabel lain konstan, jika luas panen meningkat sebesar 1 hektar akan meningkatkan 1,125 ton produksi kedelai. Jika penggunaan benih meningkat 1 ton akan meningkatkan produksi kedelai sebesar 5,833 ton dengan menganggap variabel lain konstan.

Hasil estimasi menunjukkan bahwa produksi kedelai pada minat petani 1 mengalami peningkatan. Selanjutnya, dengan menganggap variabel lain konstan produksi kedelai akan meningkat sebesar 0,303 ton pada minat petani 1 (periode 1961-1984).

Produksi kedelai mengalami peningkatan pada minat petani 2 (periode 1985-1995), yaitu sebesar 0,256 ton dengan menganggap variabel lain konstan. Peningkatan produksi kedelai tersebut lebih kecil dibandingkan dengan produksi kedelai pada minat petani sebelumnya.

Produksi kedelai meningkat pada minat petani 3 , yaitu sebesar 0,077 ton dengan menganggap variabel lain konstan. Namun, peningkatan tersebut lebih kecil dari produksi pada minat petani 2 dan minat petani 3 .

Secara matematis persamaan yang digunakan untuk proyeksi produksi kedelai terdapat pada Persamaan 3.

$\begin{aligned} Y_{t}= & -0,741+1,125 X_{1}+5,833 X_{2}+0,303 D_{1}+0,256 D_{2} \\ & +0,077 \quad D_{3} \ldots \ldots \ldots \ldots \ldots \ldots \ldots \ldots \ldots \ldots \ldots . . .13\end{aligned}$

Selanjutnya, memproyeksikan luas panen kedelai dan benih kedelai periode 2018-2020 menggunakan model ARIMA dengan data runtun waktu luas panen 1961-2015 dan benih 1961-2014. Proyeksi dengan model ARIMA merupakan proyeksi dengan menggunakan data-data historis yang ada. Menurut Santoso (2009), model ARIMA yang memenuhi kriteria yang layak untuk digunakan untuk proyeksi adalah model memiliki nilai standard error yang kecil dan residu dari model ARIMA bersifat random.

Tabel 3. Estimasi model persamaan proyeksi produksi kedelai di Indonesia.

\begin{tabular}{lrrrr}
\hline \multirow{2}{*}{ Variabel } & \multicolumn{2}{c}{ OLS } & \multicolumn{2}{c}{ FGLS } \\
\cline { 2 - 5 } Koef. & \multicolumn{1}{c}{ t-hit. } & \multicolumn{1}{c}{ Koef. } & \multicolumn{1}{c}{ t-hit. } \\
\hline Intercept & $-0,702$ & $-12,147$ & $-0,741$ & $-15,805$ \\
$\mathrm{X}_{1}$ & $1,114^{* * * * *}$ & 30,577 & $1,125^{* * * *}$ & 37,703 \\
$\mathrm{X}_{2}$ & $4,819^{* * *}$ & 4,649 & $5,833^{* * *}$ & 6,397 \\
$\mathrm{D}_{1}$ & $0,329^{* * *}$ & 12,297 & $0,303^{* * *}$ & 13,240 \\
$\mathrm{D}_{2}$ & $0,245^{* * * *}$ & 8,496 & $0,256^{* * * *}$ & 10,930 \\
$\mathrm{D}_{3}$ & $0,085^{* * *}$ & 4,298 & $0,077^{* * *}$ & 4,927 \\
\hline $\mathrm{F}$ hitung & 1166,64 & 0,000 & 2140,026 & 0,000 \\
$\mathrm{R}$ Square & 0,992 & & 0,996 & \\
St. error & 0,03891 & 0,02828 & \\
Observasi & 55 & & 54 & \\
DW & 1,546 & & \\
\hline Keterangan: & \multicolumn{5}{c}{ Sangat signifikan dengan alpha $0,01}$. \\
= Durbin-Watson.
\end{tabular}




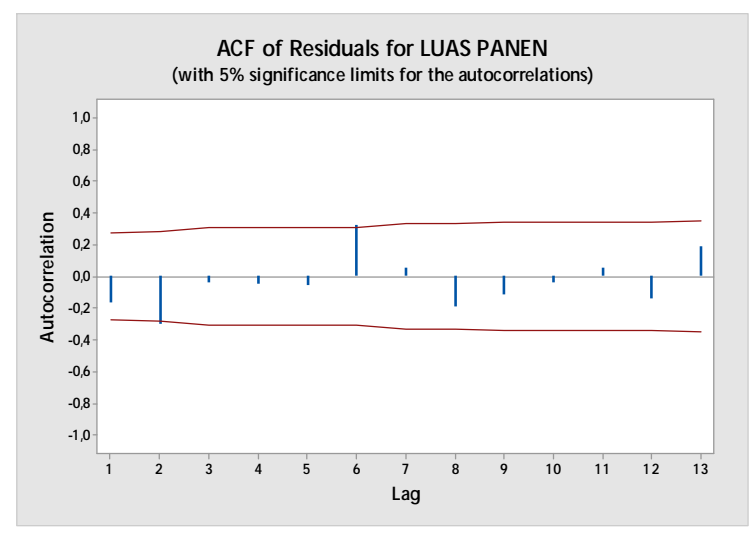

Gambar 3. Grafik fungsi autokorelasi luas panen kedelai

Hasil estimasi model ARIMA data luas panen kedelai menunjukkan bahwa residu pada model ARIMA (2,2,1) sudah bersifat random. Hal tersebut dilihat dari grafik ACF (Autocorrelation Function) (Gambar 3). Residu dari model ARIMA dikatakan sudah bersifak acak jika garis biru tidak ada yang melewati garis batas berwarna merah. Selain itu, pada persamaan estimasi model ARIMA $(2,2,1)$ memiliki nilai probabilitas (p) dibawah 0,05 yaitu nilai probabilitasnya sebesar 0,000 . Selanjutnya, model ARIMA $(2,2,1)$ memiliki tingkat kesalahan prediksi yang kecil, yang dalam hal ini dilihat dari angka MS (mean of square) kecil (Tabel 4). Berdasarkan pertimbangan tersebut maka model ARIMA $(2,2,1)$ layak digunakan untuk peramalan. Selanjutnya, penentuan model ARIMA untuk peramalan benih kedelai

Tabel 4. Output estimasi model ARIMA $(2,2,1)$ luas panen kedelai.

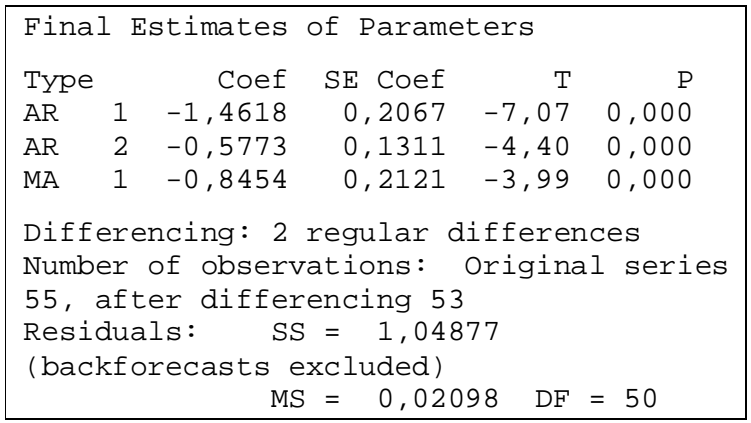

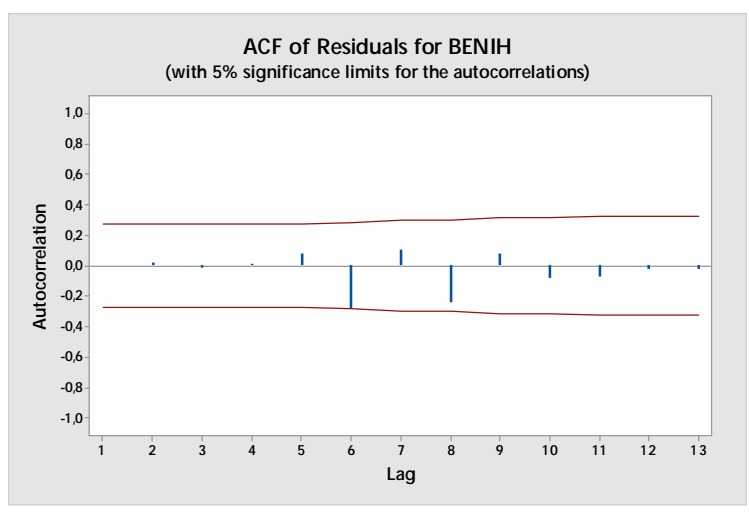

Gambar 4. Grafik fungsi autokorelasi benih kedelai

Berdasarkan hasil estimasi model ARIMA benih kedelai maka diperoleh model terbaik yaitu ARIMA $(0,2,3)$. Hal tersebut dilihat dari grafik ACF (Gambar 4) dan tabel estimasi model ARIMA $(0,2,3)$ (Tabel 5). Grafik ACF pada model ARIMA $(0,2,3)$ menunjukkan bahwa residu sudah bersifat random karena tidak ada garis biru yang melewati garis batas berwarna merah. Selanjutnya, model ARIMA $(0,2,3)$ juga memiliki nilai probabilitas dibawah angka 0,05 dan memiliki tingkat kesalahan prediksi yang kecil.

Hasil proyeksi luas panen dan benih kedelai tahun 2018-2020 dapat dilihat pada Tabel 6. Luas panen dan benih kedelai diprediksikan akan meningkat dengan laju pertumbuhan masing-masing sebesar $2,25 \%$ dan $0,29 \%$ per tahun dengan rata- 0,72 hektar dan 0,05 juta ton per tahun periode 20182020.

Hasil proyeksi luas panen dan benih kedelai dimasukkan pada model persamaan proyeksi produksi kedelai untuk mendapatkan nilai tengah. Hasil proyeksi dan selang proyeksi (batas bawah dan batas atas) produksi kedelai periode 2018-2020 dapat dilihat pada Tabel 7.

Tabel 5. Output estimasi model ARIMA $(0,2,3)$ benih kedelai.

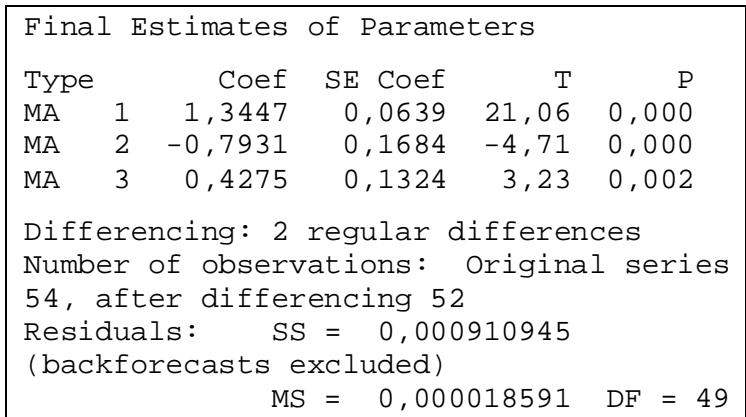


Tabel 6. Proyeksi luas panen dan benih kedelai 2018-2020.

\begin{tabular}{ccccc}
\hline Tahun & $\begin{array}{c}\text { Benih } \\
\text { (juta } \\
\text { ton) }\end{array}$ & $\begin{array}{c}\text { Pertumbuhan } \\
\text { (\%/tahun) }\end{array}$ & $\begin{array}{c}\text { Luas } \\
\text { Panen } \\
\text { (juta } \\
\text { hektar) }\end{array}$ & $\begin{array}{c}\text { Pertumbuhan } \\
(\% / \text { tahun })\end{array}$ \\
\hline 2018 & 0,0481 & $0,00 \%$ & 0,6989 & $0,00 \%$ \\
2019 & 0,0483 & $0,44 \%$ & 0,7249 & $3,73 \%$ \\
2020 & 0,0485 & $0,43 \%$ & 0,7468 & $3,01 \%$ \\
\hline $\begin{array}{c}\text { Rata- } \\
\text { rata }\end{array}$ & 0,0483 & $0,29 \%$ & 0,7235 & $2,25 \%$ \\
\hline
\end{tabular}

Tabel 7. Proyeksi produksi kedelai dan target pemerintah (juta ton)

\begin{tabular}{ccccc}
\hline Tahun & $\begin{array}{c}\text { Batas } \\
\text { Bawah }\end{array}$ & $\begin{array}{c}\text { Nilai } \\
\text { Tengah }\end{array}$ & $\begin{array}{c}\text { Batas } \\
\text { Atas }\end{array}$ & Target \\
\hline 2018 & 0,91 & 0,96 & 1,02 & 2,91 \\
2019 & 0,94 & 0,99 & 1,05 & 3,00 \\
2020 & 0,96 & 1,02 & 1,07 & \\
\hline Rata-rata & 0,94 & 0,99 & 1,05 & \\
\hline
\end{tabular}

Selanjutnya, perhitungan nilai selang proyeksi batas bawah dan batas atas. Selang proyeksi batas bawah diperoleh dari hasil pengurangan nilai tengah proyeksi dengan Margin Error (ME) (Nilai tengah - ME). Selang proyeksi batas atas diperoleh dari hasil penjumlahan nilai tengah proyeksi dengan ME (Nilai tengah $+\mathrm{ME}$ ). Nilai ME diperoleh dari hasil perkalian antara standard error dari estimasi dengan nilai distribusi $t$ (Supranto 1983). Penelitian ini menggunakan selang kepercayaan $95 \%$.

Hasil proyeksi produksi kedelai di Indonesia periode 2018-2020, menunjukkan bahwa produksi kedelai diperkirakan meningkat, dengan laju pertumbuhan $2,05 \%$ per tahun atau rata-rata sebesar 0,99 juta ton per tahun (Tabel 7). Selang proyeksi tahun 2018-2020 secara berturut-turut adalah 0,91-1,02 juta ton; 0,94-1,05 juta ton; dan 0,96-1,07 juta ton. Sementara itu, hasil penelitian Aldillah (2015), produksi kedelai tahun 2018-2020 berturut-turut adalah 1,33 juta ton; 1,41 juta ton; dan 1,48 juta ton. Dengan kata lain, nilai proyeksi Aldillah (2015) lebih besar dari nilai proyeksi selang atas pada penelitian ini.

Selanjutnya, pemerintah menargetkan produksi kedelai tahun 2018-2019 adalah 2,91 dan 3,00 juta ton. Artinya, angka proyeksi target pemerintah hampir 3 kali lipat lebih besar dari nilai proyeksi selang atas yang dihasilkan pada penelitian ini.

\section{KESIMPULAN}

Perkembangan produksi kedelai di Indonesia mengikuti fluktuasi minat petaninya. Produksi kedelai tertinggi terjadi pada periode 1985-1995 dengan selang antara $0,87-1,87$ juta ton. Produksi kedelai menurun drastis terjadi pada periode 19962007 yaitu dari 1,52 menjadi 0,59 juta ton. Hasil proyeksi dan selang proyeksi produksi kedelai secara berturut-turut 2018, 2019, 2020 yaitu 0,96 $(0,91-1,02) ; 0,99(0,94-1,05) ; 1,02(0,96-1,07)$ juta ton.

\section{DAFTAR PUSTAKA}

Aldillah R. 2015. Proyeksi produksi dan konsumsi kedelai Indonesia 2013-2020. Jurnal Ekonomi Kuantitatif Terapan, 8 (1) : 9-23. http://down load.portalgaruda.org/article.php?article=366 $175 \& \mathrm{val}=953 \&$ title $=$ Proyeksi $\% 20$ Produksi $\%$ 20Dan\%20Konsumsi\%20Kedelai\%20Indones ia. [1 Maret 2016].

BPS [Badan Pusat Statistik]. 2017. Data Produksi Kedelai Menurut Provinsi Tahun 1993-2015. https://www.bps.go.id/dynamictable/2015/09/ 09/871/produksi-kedelai-menurut-provinsi-to n-1993-2015.html. [1 Maret 2017].

BPS [Badan Pusat Statistik]. 2017. Data Luas Panen Kedelai Menurut Provinsi (ha), 19932015. https://www.bps.go.id/dynamictable /2015/09/09/870/luas-panen-kedelai-menurutprovinsi-ha-1993-2015.html. [1 Maret 2017].

FAO [Food and Agriculture Organization]. 2017. Statistical Database of Food Balance Sheet. FAOSTAT. http://www.fao.org/faostat/en/\# data/FBS. [8 April 2017].

FAO [Food and Agriculture Organization]. 2017. Statistical Database of Crops. FAOSTAT. http://www.fao.org/faostat/en/\#data/QC. [8 April 2017]

Supranto J. 1983. Ekonometrika Buku dua. Lembaga Penerbit Fakultas Ekonomi Universitas Indonesia. Jakarta.

Kementerian Pertanian. 2015. Rencana Strategis Kementerian Pertanian 2015-2019. http:// www.pertanian.go.id/file/RENSTRA_2015-2 019.pdf. [20 Juni 2016]

Komalasari WB. 2008. Prediksi Penawaran dan Permintaan Kedelai dengan Analisis Deret Waktu. Informatika Pertanian, 17(2): 11951209. 2008. http://www. litbang. pertanian. go.id/warta-ip/pdf-file/4.wieta_ipvol17-2-20 08.pdf. [29 Juni 2016].

Lestari AM, Hudoyo A, Kasymir E. 2015. Proyeksi produksi dan konsumsi telur ayam ras di Provinsi Lampung. JIIA, 3(3): 287-293. 


\section{JIIA, VOLUME 6 No. 3, AGUSTUS 2018}

https://media.neliti.com/media/publications/1 3354-ID-proyeksi-produksi-dan-konsumsi-tel ur-ayam-ras-di-provinsi-lampung.pdf. [26 April 2016].

Mubyarto. 1989. Pengantar Ekonomi Pertanian. Edisi Ketiga, LP3S. Jakarta
Santoso S. 2009. Business Forecasting: Metode Peramalan Bisnis Masa Kini dengan Minitab dan SPSS. PT Elex Media Komputindo. Jakarta. 